\title{
Geological Characterisation of Depleted Oil and Gas Reservoirs for Carbon Sequestration Potentials in a Field in the Niger Delta, Nigeria
}

\section{$*^{1}$ OJO, AJOKE CELINAH ${ }^{2}$ TSE, AKAHA CELESTINE}

\author{
Department of Geology, University of Port Harcourt, Nigeria \\ E-mail: harjork@yahoo.com GSM +2348063591874 \\ Department of Geology, University of Port Harcourt, Nigeria \\ E-mail: akaha.tse@uniport.edu.ng GSM +2348055364149
}

\begin{abstract}
The injectivity, containment and storage capacity of sandstone reservoirs in a field in the Coastal Swamp depobelt of the onshore eastern Niger Delta were evaluated using wireline $\operatorname{logs}$ and seismic data to assess their potentials for carbon dioxide storage and geosequestration. The reservoir formation consists of multilayered alternating beds of sandstone and shale cap rocks. Active seismicity and fracturing intensity are low and growth faults provide the reservoir sealing mechanisms. Three reservoirs were delineated at depths between $3319 \mathrm{~m}$ and $3539 \mathrm{~m}$ which will keep injected $\mathrm{CO}_{2}$ in a supercritical state. The reservoir depth of at least $800 \mathrm{~m}$, porosity and permeability of more than 10 percent and $20 \mathrm{mD}$, and a caprock thickness of at least $10 \mathrm{~m}$, in addition to geothermal gradients of 13.46 to $33.66^{\circ} \mathrm{C} / \mathrm{km}$ are the ideal conditions for the efficacy of storage. Comparison of the derived reservoir and seal properties such as porosity, permeability, thickness and depth with the minimum recommended site selection criteria shows that the reservoirs are potential candidates for carbon geosequestration with a total theoretical storage capacity of 147MM tons. ( JASEM
\end{abstract}

\section{http://dx.doi.org/10.4314/jasem.v20i1.6}

Keywords: reservoirs, carbon geosequestration, Niger Delta, carbon dioxide, injectivity, containment.

\section{INTRODUCTION}

The world development indicators (Word Bank 2015) show that Nigeria is rated number 39 in the world ranking of carbon emissions from all sources, the emissions rising from $3,406.6 \mathrm{kt}$ in 1960 to $88,026.3 \mathrm{kt}$ in 2011 , and contributing $0.3 \%$ of the global total emissions. In the oil sector, Nigeria is one of the highest emitters of greenhouse gases in Africa, flaring 1.4 billion cubic feet of associated gas every day corresponding to about $40 \%$ of produced gas from 123 flaring sites and re-injecting $12 \%$ to enhance oil recovery in the Niger Delta region (Onyekonwu 2008). This ranks the country only second behind Russia in terms of worldwide gas flaring (OPEC 2014). Industrial emission and flaring of associated gas release vast amounts of $\mathrm{CO}_{2}$ together with a variety of air pollutants, such as carbon monoxide (CO), VOCs, nitrogen oxides $\left(\mathrm{NO}_{\mathrm{x}}\right)$, sulphur dioxide $\left(\mathrm{SO}_{2}\right)$ and toxic heavy metals, and has a profound effect on the carbon cycle equilibrium. The emissions represent pollution equivalent to between 35 to 45 million tons of carbon dioxide per day (Ologunrisa 2014), contributing substantially to the approximately 300 million tons of carbon dioxide $\left(\mathrm{CO}_{2}\right)$ being emitted daily to the atmosphere worldwide. Carbon dioxide has attracted worldwide attention for being the reason for global warming and the consequent potential threats to human beings. Therefore, there is a need to stabilize greenhouse gas concentrations in the atmosphere in order to meet targets for greenhouse gas emission reduction set by the Kyoto Protocol, and to achieve the goal of the United Nations (UN) Framework Convention on Climate Change. One suggested remedy to reduce $\mathrm{CO}_{2}$ emissions is to capture it from point sources prior to its release into the atmosphere and inject into deep subsurface formations for longterm storage and sequestration (IEA 2008). Carbon geosequestration involves the capturing of carbon dioxide which would have been emitted into the atmosphere, converting it to a supercritical state, transporting it to a suitable site and injecting it into deep geologic formations, including depleted oil and gas reservoirs, deep saline aquifers, deep coal seams and salt caverns. This requires a site characterization of the formations to determine the optimum conditions for long term storage that will protect health and safety of human beings and the environment. The characterization is a three phase process which involves determination of the capacity of the reservoirs to store the intended volume of carbon over the lifetime of the operation, injectivity to accept/take carbon at the rate that it is supplied from the sources, and containment which ensures that it will not migrate or leak out of the storage (Griffiths et al, 2005). The process has been exhaustively discussed by IEAGHG (2000,) Shaw and Bachu 
(2002), IPCC (2005), Kaldi and Gibson-Poole (2009), IEA (2009), Godec, et al. (2013).

As an important petroleum provider and greenhouse emitter in Africa, hydrocarbon exploration and production in Nigeria since 1957 has led to depletion and abandonment of some reservoirs in brownfields in the Niger Delta which may be used for carbon capture and geological storage to achieve reduction in $\mathrm{CO}_{2}$ emissions in line with UN Framework Convention on Climate Change. This requires knowledge of the available geological storage capacity. Other than a model developed to study the possible alteration of porosity and permeability during future carbon dioxide injection on selected Niger Delta reservoir rocks and fluids (Thomas et al. 2014) and a review of carbon capture and storage processes (Akpanika et al. 2015), the capacity of subsurface rocks in the Niger Delta for carbon geosequestration has not been previously evaluated compared to extensive studies in many countries, mainly the developed countries including Australia (Kaldi and Gibson-Poole 2008, Sayers et al. 2013), Canada (Bachu 2006), the Middle East (Algharaib 2013), Netherlands (Ramirez et al. 2009), Norway (Solomon 2007), and United States (Winter and Bergman 1993), which have carried out their carbon capture and storage (CCS) programmes, including the fundamental work of carbon storage capacity estimation among others. Friedman et al. (2005) identified three levels of geologic carbon storage assessment implying decreasing area coverage: basin level, individual formation evaluation and individual sequence evaluation and assessment.

This work attempts to assess the potentials of depleted oil and gas reservoirs of a field in the Niger Delta that will be suitable for carbon dioxide geosequestration by delineating the hydrocarbon bearing zones and evaluating the storage capacity, injectivity and containment of the reservoirs at individual formation evaluation level. Some proprietary well $\operatorname{logs}$ and seismic data of an anonymous oil field in the Niger Delta were evaluated for its suitability and capacity for carbon storage.

\section{GEOLOGICAL SETTING}

The area under investigation, outlined in Fig. 1, is located in the coastal swamp depobelt of the eastern Niger Delta. The Niger Delta is situated in the Gulf of Guinea in a rift triple junction related to the opening of the southern Atlantic started in the Late Jurassic to the Cretaceous. It is located between latitudes $4^{\circ}$ and $6^{\circ} \mathrm{N}$ and longitudes $4^{\circ} 30^{\prime}$ and $8^{\circ} 00^{\prime} \mathrm{E}$ and is one of the world's most prolific petroleum producing Tertiary deltas. The geology of the Niger Delta has been described extensively by Short and Stauble (1967) and Doust and Omatsola (1990). The lithostratigraphic subdivision of the Niger delta subsurface, comprise an upper sandy Benin Formation, an intervening unit of alternating sandstone and shale named the Agbada Formation, and a lower shaly Akata Formation. These three units extend across the whole delta and each ranges in age from early Tertiary to Recent. A separate member of the Benin Formation, the Afam clay member, which is interpreted to be an ancient valley fill formed in Miocene sediments, is recognized in the Port Harcourt area. The basal Akata Formation, Paleocene to Recent in age is a pro-delta lithofacies composed mainly of marine shales, with sandy and silty beds which are thought to have been laid down as turbidites and continental slope channel fills. It is the source rock which is estimated to be up to 7,000 metres thick. It is overlain by the Agbada Formation, Eocene to Recent in age. It is a delta front lithofacies consisting mostly of shoreface and channel sands with minor shales in the upper part, and alternation of sands and shales in the lower part. Within the Agbada Formation occur structures described as resulting from movement under the influence of gravity. Generally, structural traps and seals are predominant over stratigraphic traps. These include traps associated with simple rollover structures such as clay filled channels, structures with multiple growth faults, structures with antithetic faults, and collapsed crest structures. The primary seal rock in which are the interbedded shale within the Agbada Formation provide three types of seals namely: clay smears along faults, interbedded sealing units against which reservoir sands are juxtaposed due to faulting, and vertical seals (Doust and Omatsola, 1990). The rollover anticlines which occur in front of growth faults are the target of oil exploration. The Agbada Formation is the major reservoir from which oil is produced primarily from gas expansion. These reservoirs have average porosity of $40 \%$ and permeability of 2 darcies. Reservoir thickness ranges from less than 15 meters to $10 \%$ having greater than 45 meters' thickness although thicknesses of 100 meters may be encountered (Edwards and Santogrossi 1990). The delta contains only one identified petroleum system referred to as Tertiary Niger Delta Petroleum System. The overlying Benin Formation consists of coarse grained, gravelly, poorly sorted, sub-angular to well-rounded sand. It is the most prolific aquifer in the region and comprises over $90 \%$ massive, porous sands with localized clay/shale inter-beds. Onshore, the delta is divided into five extensional depobelts: Northern Delta, Greater Ughelli, Central Swamp, Coastal Swamp and 
Shallow Offshore depobelts. Sediments contained in these depobelts become progressively younger seaward. These depobelts are $30-60$ kilometers wide, prograde southwestward 250 kilometers over oceanic crust into the Gulf of Guinea, and are defined by syn-sedimentary faulting resulting from variable rates of subsidence and sediment supply (Ahiarakwem and Opara, 2012). Detailed information on the occurrence of groundwater in the Niger delta obtained from Etu-Efeotor and Akpokodje (1990) indicates that the aquifers range from localized, shallow unconfined aquifers up to $400 \mathrm{~m}$ in the subsurface to deeper, laterally more extensive ones. The deeper aquifers may contain several clay layers which subdivide them into series of aquifers/subaquifers which are essentially independent units without hydraulic interconnection. These intermediate and regional-scale flow characteristics are desirable for storage site selection.

\section{MATERIALS AND METHODS}

For carbon dioxide to be stored in depleted oil and gas reservoirs, site characterization and selection are important in ensuring the intergrity of the project. The process involves determination of the capacity of the reservoirs to store the intended volume of $\mathrm{CO}_{2}$ over the lifetime of the operation, injectivity to take $\mathrm{CO}_{2}$ at the rate that it is supplied from the sources and containment which ensures that it will not migrate or leak out of the storage (IEAGHG 2008). Although data for 15 wells in the field were examined, only 3-D seismic and a suite of wireline logs (Gamma Ray GR, Spontaneous Potential SP, Resistivity and Neutron log) for six wells codenamed TAJ were readily available in raster format, and were digitized and used for this study. The GR and SP logs were used for lithology discrimination and delineation of the reservoirs in conjunction with the resistivity logs. The wells were correlated using both the logs and seismic data to determine the continuity and equivalence of lithologic units, particularly reservoir sands and marker sealing shales as described by Tearpock and Bischke (1991). Events or markers of sand bodies having high resistivity that are laterally continuous and present in all the wells were identified and correlated to determine the extent of the reservoir and the thickness of the caprock. An integration of the 3D seismic data and wireline logs were used to delineate the sealing faults and trapping mechanism and identify potential leakage paths into overlying strata. Vertical patterns in seismic reflections were used to relate strata across faults. The reservoir tops and bottoms on the logs were then interpreted along the corresponding seismic lines and the reservoir surface generated in three dimensions.
The stratigraphic surfaces and faults delineated in the seismic data were converted to depth and loaded in to PETREL software developed by Schlumberger to model the geometry and spatial relationships between stratal surfaces and faults in the field. Also, the logs were used to produce a geophysical and geological evaluation of the field following which stratigraphic surfaces and faults were adjusted to the logs to define stratigraphic positions. Four reservoir sands, A, B, C and $\mathrm{D}$ were identified and correlated across the wells but only A, B and D were used for this study because of their lateral continuity across the wells. Reservoir $\mathrm{C}$ had no appreciable stratigraphic thickness and so was excluded. Data from the logs were used to determine the porosity, permeability, volume of shale, water saturation, hydrocarbon saturation, netto-gross and fractional total pore volume filled with hydrocarbon after the Timur (1968) and Tixier et al, (1949) methods. Geothermal gradients and formation pressures were obtained from the works of Adedapo et al. (2014) and Emojakporue and Ekine (2014).

Determination of the field's petrophysical parameters which were used for the volumetric estimation of the hydrocarbon in the reservoirs was facilitated by wireline logs. The indirect method of porosity determination from the density log was adopted using the Tixier et al. (1949) formula as in equation 1
Porosity $=$
$\frac{\rho \mathrm{ma}-\rho \mathrm{b}}{(\rho \mathrm{ma}-\rho \mathrm{fl})}$

Where $\rho_{\text {ma }}$ is the density of matrix, $\rho_{b}$ is the bulk density, and $\rho_{\mathrm{fl}}$ is the density of fluid.

Injectivity which defines the ability to pump fluid or gas into a rock, was obtained by the determination of permeability $(\mathrm{K})$ using the Timur equation

$\mathrm{K}=307+26552\left(\phi^{2}\right)-34540(\phi \times \mathrm{Sw})^{2}$

where $\phi=$ porosity and $\mathrm{Sw}=$ Water saturation

Hydrocarbon saturation $\left(\mathrm{S}_{\mathrm{h}}\right)$ is the fraction or percentage of the pore volume of the rock that is filled with hydrocarbons. It is determined from the water saturation by

$$
\mathrm{S}_{\mathrm{h}}=1-\mathrm{S}_{\mathrm{W}}
$$

Where, $S_{h}=$ Hydrocarbon saturation

The higher the value of $\mathrm{Sw}$ in the reservoir sand, the lower the hydrocarbon and vice versa.

The net to gross (NTG) refers to the proportion of clean sand to shale within a reservoir unit and is a measure of the potential of productive part of the reservoir expressed either as a percentage of the producible (net) reservoir within the overall (gross) reservoir packages or as a ratio. It could be expressed by equation 5 as:

Net-to-Gross $=\frac{\text { Net thickness }}{\text { Gross thickness }} \times 100 \%$

This ratio reflects the quality of the sands as potential reservoirs (Udegbunam 2008). 
Storage capacity is determined by five parameters, namely: formation thickness, area of the storage capacity, rock porosity, $\mathrm{CO}_{2}$ density and storage efficiency. Generally, the storage parameters were determined according to the methods of DOE (2008) and CSLF (2010).

In order to estimate the hydrocarbon volume in place, the porosity, water saturation and net to gross value of the reservoirs were used as shown in equation 6 STOIIP $=\frac{7758 \times \text { Area } x \text { Thickness } \times \phi \times(1-S w) \times \text { NTG }}{\text { FVF }}$

where: STOIIP $=$ Stock tank oil initially in place, $\phi=$ porosity, $\mathrm{Sw}=$ Water saturation, $\mathrm{NTG}=$ Net to gross ratio, Thickness $=$ thickness of the reservoir, Area $=$ area of the reservoir and FVF = Formation volume factor which is a constant

The volume of the hydrocarbon that was produced from the reservoirs $\left(\mathrm{V}_{\mathrm{H} \text { produced }}\right)$ was determined from equation 7 as

$\mathrm{V}_{\mathrm{H} \text { produced }}=\frac{\% \mathrm{H} \text { produced }- \text { Total STOIIP }}{100}$

The storage capacity was estimated from the total mass of carbon dioxide that can be stored in a depleted oil reservoir according to equation 8 (Bachu et al., 2007):

$\mathrm{M}_{\mathrm{CO} 2}=\mathrm{C}_{\mathrm{ef}} \times \mathrm{R}_{\mathrm{f}} \times$ OOIP $\times \mathrm{B}_{\mathrm{o}} \times \rho_{\mathrm{CO} 2}$

where $\mathrm{M}_{\mathrm{CO} 2}$ is the mass of $\mathrm{CO}_{2}$ that can be stored $\left(\mathrm{M}_{\mathrm{ton}}\right), \mathrm{C}_{\mathrm{ef}}$ is the storage efficiency coefficient, $\mathrm{R}_{\mathrm{f}}$ is the recovery factor, OOIP is the original oil in place, $\mathrm{B}_{\mathrm{o}}$ is the formation volume factor, and $\rho_{\mathrm{CO} 2}$ is the density of $\mathrm{CO}_{2}\left(\mathrm{~kg} / \mathrm{m}^{3}\right)$.

The critical elements of the confinement of $\mathrm{CO}_{2}$ are sealing faults and the cap rock overlying the storage formation. The faults were determined from the seismic sections while the cap rocks were determined by the thickness, lithology, depth and the lateral continuity of the overlying shale. All storage sites need to be confined by an impervious or low permeability overlying stratum that will impede upward $\mathrm{CO}_{2}$ movement and subsequent leakage. Sealing faults commonly trap hydrocarbons and compartmentalize oil and gas reservoirs and could also form suitable confining barriers at $\mathrm{CO}_{2}$ storage sites (WRI, 2008).

\section{RESULTS AND DISCUSSIONS}

From the correlation panel of the wells (Fig. 2), four reservoirs $\mathrm{A}, \mathrm{B}, \mathrm{C}$ and $\mathrm{D}$ were delineated. However, only reservoirs $\mathrm{A}, \mathrm{B}$ and $\mathrm{D}$ were modeled and used for this study because of their lateral continuity and significant stratigraphic thickness across the six wells unlike reservoir $\mathrm{C}$ which lacks these key attributes. The depth structure maps produced for the reservoirs and the interpreted inline of the 3D seismic volumes are shown in Fig.3. The dark lines on the depth map represent the extracted faults. The faults enclosed the reservoirs and conformed to the typical Niger Delta hydrocarbon trapping pattern of fault enclosed hydrocarbon reservoirs. The seismic section in Fig. 4 revealed five listric faults and the reservoir horizons. These growth faults are the normal faulting patterns characteristics of reservoirs in the Niger Delta and are often associated with roll over anticlines. The seismic continuity and seismic to well correlation were used to identify and map the three candidate horizons used in this study. The reservoirs were located at depths of between 3319 and $3539 \mathrm{~m}$ across the wells with thicknesses varying from 24 to $73 \mathrm{~m}$. The corresponding cap rock thicknesses fall between 21 and $76 \mathrm{~m}$.

The derived petrophysical properties of the reservoirs in the six wells are shown in Tables 1. The calculated porosity values of the three reservoirs range from 0.15 to 0.21 while net to gross ratio ranged from 0.44 to 0.67 suggesting good quality reservoir sands. The water saturation ranged from 0.43 to 0.57 . The entire reservoir surface has very good permeability values which range from $768 \mathrm{mD}$ to $1394 \mathrm{mD}$.

These petropysical parameters were used in the estimation of the volume of hydrocarbon and storage capacity of the delineated reservoirs. Results show that the stock tank oil in place for reservoirs A, B and $\mathrm{D}$ are $27.23,6.12$ and $184.74 \mathrm{mmstb}$ respectively. The average oil recovery factor worldwide is only between $20 \%$ and 40\%, (Muggeridge et al. 2013), thus the average recovery factor in a hydrocarbon well in the Niger Delta based on the average global recovery factor of $35 \%$ of stock tank oil initially in place (Egbogah 2012) was adopted to estimate recoverable hydrocarbon. Therefore, the hydrocarbon produced from the three reservoirs are 9.53, 2.14 and 64.66 mmstb respectively as shown in Table 2

The theoretical sequestration capacity represents the mass of $\mathrm{CO}_{2}$ that can be stored in the hydrocarbon reservoirs. The storage efficiency of the sandstone reservoirs was estimated as described by DOE (2005, 2008) using the relationship:

$\mathrm{SC}=\varnothing_{\mathrm{h}} * \rho \mathrm{CO}_{2} * \xi * \mathrm{~A} * \mathrm{C}$

where $\mathrm{SC}=\mathrm{CO}_{2}$ storage capacity in metric tons; $\emptyset_{\mathrm{h}}=$ net porosity; $\rho \mathrm{CO}_{2}=\mathrm{CO}_{2}$ density; $\xi=$ storage efficiency of $1 \%$ and $4 \%, \mathrm{~A}=$ area in $\mathrm{km}^{2}$; and $\mathrm{C}=\mathrm{a}$ constant for unit conversion to metric tons.

Storage efficiency, $\xi$, is a critical parameter obtained from volumetric and reservoir performance parameters that reflect what portion of the subsurface will actually be occupied by carbon dioxide and how 
that $\mathrm{CO}_{2}$ will move through the reservoir. The volumetric portion of $\xi$ takes into account three factors: gross thickness to net thickness, total porosity to effective porosity, and total area to net area in the basin that has a suitable formation for injection. DOE (2008) suggests a range of values between $1-4 \%$ for overall efficiency. However, to incorporate a substantial decrease in uncertainty through consideration of net thickness, porosity, and area calculated from specific wells and regional patterns in the reservoir quality rock, it is recommended to work with values of efficiency factors $(\xi)$ of $10 \%$ and $15 \%$ in addition to the recommended values of $1 \%$ and $4 \%$ (Medina et al. 2010, Goodmana, et al. 2010). Following this method, the storage capacity was estimated on the assumption that all the pore spaces of the reservoirs can store $\mathrm{CO}_{2}$. The resultant values for the total storage capacity taking into account the efficiency factors are shown in Table 3.

Geological sequestration of anthropogenic carbon dioxide from stationary emissions sources constitutes an important component of the greenhouse gas emissions reduction strategy that is commonly referred to as carbon capture and storage. The feasibility of cost-effective geo-sequestration in any area depends on local and suitable geological sequestration systems, including effective reservoir zones for injection and storage and stratigraphically related seals for confinement. The geological sequestration system must lie at a depth within the subsurface sufficient to retain $\mathrm{CO}_{2}$ in supercritical state possess sufficient injectivity and storage capacity for the scale of the project under consideration, and have injection and confining zone characteristics that preclude buoyant, supercritical $\mathrm{CO}_{2}$ escape over long periods of time, generally accepted to exceed at least 1,000 years (DOE 2008). In this study, the depleted hydrocarbon reservoirs are considered ideal for carbon storage and geosequestration. The rocks that have stored hydrocarbon in the Niger Delta range in age from Paleocene to Oligocene which implies a geologic time period of at least 65 million years since hydrocarbon was formed. Over this period the sealing faults in the field have been able to prevent the oil and gas initially present in the reservoir from infinite lateral migration which is a critical requirement for containment of fluids. The space available for storage in a depleted reservoir depends on the spore volume previously occupied by the produced hydrocarbon and the compaction of the pore spaces. The major lithologies encountered in the reservoir units are sand and shale. This is an indication that the lithology is within the Agbada Formation. The reservoir and caprock properties values were compared with the IEAGHG (2009) criteria (Table 4) for ideal carbon geosequestration sites. Permeability ranges from 768 to $1393 \mathrm{mD}$ which is sufficient to enhance injectivity. Storage of $\mathrm{CO}_{2}$ at the depths of 3310 to $3539 \mathrm{~m}$ within which the reservoirs occur in this field will keep the $\mathrm{CO}_{2}$ in a super critical state, and the high density will compress it for ease of transportation to the storage site. The shale cap rock with a thickness of 41 to $68 \mathrm{~m}$ is robust enough to impede the leakage and escape of injected $\mathrm{CO}_{2}$. The theoretical sequestration capacity represents the mass of $\mathrm{CO}_{2}$ that can be stored in hydrocarbon reservoirs assuming that the volume occupied previously by the produced oil or gas will be occupied by the injected gas.

Adedapo et al. (2014) used data of subsurface temperatures measured from continuous temperature $\operatorname{logs}$ of wells drilled for the study of natural subsurface temperature of rock formations and geothermal gradients in the Niger Delta. Results of their work indicate that minimum geothermal gradient value of $1.2^{\circ} \mathrm{C} / 100 \mathrm{~m}$ is found at the central part of the basin while maximum value is $7.62^{\circ} \mathrm{C} / 100 \mathrm{~m}$ obtained at the northeastern part of the basin with the mean background geothermal gradient value over the area of $3.29^{\circ} \mathrm{C} / 100 \mathrm{~m}$. However, in the eastern Niger Delta the geothermal gradient obtained from bottom hole temperatures of exploratory oil wells vary from 13.46 to $33.66{ }^{\circ} \mathrm{C} / \mathrm{km}$ with an average of $23.56{ }^{\circ} \mathrm{C} / \mathrm{km}$ (Emojakporue and Ekine 2014). These geothermal gradient values were adopted to represent the conditions in the study area which is part of the Agbada Formation. These reservoir properties satisfy the desirable site criteria advantageous for ensuring the safety and security of $\mathrm{CO}_{2}$ storage. Site selection and characterization is of critical importance because storage site must have capacity to store the intended volume of $\mathrm{CO}_{2}$ over lifetime of operation, to accept and take it at the rate that it is supplied and ensure that the $\mathrm{CO}_{2}$ will not leak out of the storage unit

Conclusions : Hydrocarbon exploration and production for almost seventy years has led to depletion and abandonment of some wells in the Niger Delta. The objective of this study was to estimate the storage capacity of reservoirs in these wells in a brown field in the Niger Delta as possible carbon storage sites. Reservoir thickness and porosity were used to determine the pore volume of depleted reservoirs and hence the storage capacity. Reservoirsseal pairs are multilayered and consist of extensive 
and competent barrier to vertical flow. The desirable criteria of reservoir depth and thickness of at least $800 \mathrm{~m}$ and $20 \mathrm{~m}$ respectively, porosity and permeability of more than $10 \%$ and $20 \mathrm{mD}$ and a caprock thickness of at least $10 \mathrm{~m}$ obtained in the target reservoir units provide the favourable conditions for the efficacy of carbon storage. Comparison of the derived reservoir and seal properties such as porosity, permeability, thickness and depth and availability of caprocks and sealing structures with the minimum recommended site selection criteria shows that the reservoirs are potential candidates for carbon geosequestration with a total storage capacity of 147MM tons.

Acknowledgements: The authors are grateful to the Department of Petroleum Resources and Shell Petroleum Development Company of Nigeria for making available data for this study. Our thanks also go to Schlumberger for the use of the PETREL software donated to the Department of geology, University of Port Harcourt and to the anonymous reviewers for their contributions and suggested corrections.

\section{REFERENCES}

Adebayo, TA. (2013) Implication of Future Carbon Dioxide Injection on Selected Niger Delta Reservoirs and Fluids. PET PhD Thesis. Covenant University. URI:http://hdl.handle.net/123456789/201. Accessed online 21/6/15

Adedapo, JO; Ikpokonte, AE; Schoeneich, KE and Kurowska, E; (2014). An Estimate of Oil Window in Nigeria Niger Delta Basin from Recent Studies. American International Journal of Contemporary Research Vol. 4, No. 9; September 2014

Ahiarakwem, CA; Opara, AI (2012). Application of Brine Concentrations as a Reconnaissance Geochemical Tool for Hydrocarbon Exploration: Case Study of Field "X", OML63, Coastal Swamp 1 Depobelt, Niger Delta Basin, Nigeria. International Journal of Science and Technology Volume 2 No.8, p.507-516

Akpanika, OI; Etim JO; Udoh, F D (2015) Diverting $\mathrm{CO}_{2}$ Emissions from the Atmosphere through Capture and Geologic Sequestration: The Journey So Far! Journal of Environment and Earth Science Vol.5, No.2, pp. 42-52
Bachu, S (2000) Sequestration of Carbon Dioxide in Geological Media: Criteria and Approach for Site Selection in Response to Climate Change. Energy Conversion and Management. 41(9), pp. 953 - 970.

CSLF (Carbon Sequestration Leadership Forum), 2010. Task Force for Review and Identification of Standards for $\mathrm{CO}_{2}$ Storage Capacity Estimation. http://www.cslforum.org/.

DOE. (2005) A Regional Characterization and Assessment of Geologic Carbon Sequestration Opportunities in the Upper Cambrian Mount Simon Sandstone in the Midwest Region. Midwest Regional Carbon Sequestration Partnership. Phase II Topical Report October 2005-October 2010. U.S. Department of Energy. 40p.

DOE/NETL, (2008) Carbon Sequestration Atlas of the United States and Canada (Atlas II), Online ed. National Energy Technology Laboratory, Morgantown, WV,

http://www.netl.doe.gov/technologies/carbon_seq/ref shelf/atlasII/atlasII.pdf.

Doust, H; Omatsola, E (1990) Niger Delta. In: Divergent/Passive Margin Basins. in Edwards, J.D. and P.A. Santogrossi (Eds.). AAPG Memoir, 48: Tulsa AAPG, pp: 239-248.

Edwards, J D; Santogrossi, PA (1990). Summary and conclusions, in, Edwards J.D., and Santogrossi P.A., eds., Divergent/passive Margin Basins, AAPG Memoir 48: Tulsa, American Association of Petroleum Geologists.

Egbogah, E (2012) Nigeria Oil and Gas Industry: Yesterday, Today and Guidelines for Tomorrow. Inaugural Lecture to mark the opening of a new chapter of National Association of Petroleum Explorationists, NAPE, in Abuja. NAPE Newsletter, August 2012.http://www.nape.org.ng/news/generalnews/ item/download/23_91f8ab42278fac4695be250a2 c403817

Emujakporue, A G; Ekine A S (2014) Determination of Geothermal Gradient in the Eastern Niger Delta Sedimentary Basin from Bottom Hole Temperatures. Journal of Earth Sciences and Geotechnical Engineering, vol. 4, no. 3, 2014, p. 109-114 
Etu-Efeotor, J O; Akpokodje, E G (1990) Aquifer Systems of the Niger Delta. Journal of Mining and Geology. 26(2), pp. $279-284$.

Friedman, S J; Dooley, J J; Held, H; Edenhofer. O (2005) The Low Cost of Geological Assessment for Underground $\mathrm{CO} 2$ Storage: Policy and Economic Implications. Energy Conversion and Management. Vol.47 p.1894-1901.

Godec, M; Koperna, G; Petrusak, R; Oudinot, A (2013) Assessment of Factors Influencing CO2 Storage Capacity and Injectivity in Eastern U.S. Gas Shales. Energy Procedia vol.37,np.66446655

Goodmana, A, Hakalaa, A; Bromhal G; Deel, D; Rodosta, T; Frailey S; Small, M; Allene, D; Romanova, V; Fazioa, J; Huertaa, N; McIntyre, D; Kutchkoa, B; Guthriea, G (2010) U.S. DOE methodology for the development of geologic storage potential for carbon dioxide at the national and regional scale. International Journal of Greenhouse Gas Control 5 (2011) 952-965

Griffiths, M; Cobb, P; Marr-Laing, T (2005) Carbon Capture and Storage: An Arrow in the Quiver or a Silver Bullet to Combat Climate Change? A Canadian Primer. The Pembina Institute. p. 77.

IEA GHG, (2009) CO2 Storage in Depleted Oil Fields" IEA-GHG technical study report no. 2009/12

International Energy Agency (IEA) Greenhouse Gas Research and Development Programme, (2000) Barriers to Overcome in Implementation of Carbon Dioxide Capture and Storage - Storage in Disused in Oil and Gas fields, Report Number PH3/22. p. 146.

International Energy Agency (IEA) Greenhouse Gas Research and Development Programme (2008). Geologic Storage of Carbon Dioxide, Staying Safely Underground. pp. $2-13$

International Panel on Climate Change (IPCC), (2005) IPCC Special Report on Carbon Dioxide Capture and Storage. Prepared by Working Group III of the Intergovernmental Panel on Climate Change. Cambridge University Press, Cambridge, United Kingdom and New York, USA. p. 442.

Kaldi, JG; Gibson-Poole, C M (Eds.) (2008) Storage Capacity Estimation, Site Selection and
Characterization for Carbon Dioxide Storage Projects. $\mathrm{CO}_{2} \mathrm{CRC}$, Canberra, Australia. Report No: RPT08-1001.

Medina C; Rupp J; Avary K L; Venteris E R; Barnes D A; Harper J A; Greb S; Slater, BE; Stolorow, A; Sminch J (2010) A Regional Characterization and Assessment of Geologic Carbon Sequestration Opportunities in the Upper Cambrian Mount Simon Sandstone in the Midwest Region MRCSP Phase II Topical Report October 2005-October 2010

Muggeridge, A; Cockin, A; Webb, K; Frampton, H; Collins, I; Moulds, T; Salino, P (2013) Philosophical Transactions A.

2013.DOI: 10.1098/rsta.2012.0320.

Ologunorisa, TE. (2014) A review of the effects of gas flaring on the Niger Delta environment, International Journal of Sustainable Development \& World Ecology, 8 (3). 249-255,

Onyekonwu, M (2008) Best practices and policiesthe Nigerian Oil and Gas industry policy problems. Port Harcourt petroleum review, vol.1 No1 14pp

Organisation of Petroleum Exporting Countries, OPEC, (2014) Annual Statistics Bulletin. OPEC Vienna Austria. P. 31

Ramírez, A; Hagedoorn, S; Kramers, L; Wildenborg, T; Hendricks, C (2009) Screening Carbon Dioxide storage options in the Netherlands. International Journal of Greenhouse Gas Control. 4(2), pp. $367-380$.

Sayers J; Marsh C; Scot A; Cinar Y; Bradshaw J; Hennig A; Barclay, S; Daniel R (2013) Assessment of a potential storage site for carbon dioxide: A case study, southeast Queensland, Australia. Environmental Geosciences. v. 13 no. 2 p. $123-142$

Short, K C; Stauble, A J; (1967) Outline of the Geology of the Niger Delta. AAPG Bulletin. 51, pp. $761-779$.

Solomon, S (2007) Carbon Dioxide Storage: Geological Security and Environmental Issues Case Study on the Sleipner Gas Field in Norway. Bellona Report. p. 128.

Tearpock, D J; Bischke, R E; (1991) Applied Subsurface Geological Mapping. Prentice-Hall, New Jersey, USA. 1st Edition. p. 648. 
Thomas, A; Churchill, A; and Fredrick, H; (2014) Permeability model for Nigerian oil sand as candidate $\mathrm{CO} 2$ storage reservoir. Advances in Petroleum Exploration and Development, 8(2), 48-52.

Timur, A (1968) An investigation of permeability, porosity and residual saturation relationship for sandstone reservoirs. Log Anal., 9: 8-8
Tixier, M P (1949) Evaluation of Permeability from Electric Log Resistivity Gradients. Oil and Gas Journal. 8, pp. 75 - 90.

World Bank (2015) World Development Indicators. Available online at data.worldbank.org/country/Nigeria. Accessed $12^{\text {th }}$ November 2015

WRI, World Resources Institute (2008) Carbon Capture and Storage Guidelines: Guidelines for Carbon Dioxide Capture, Transport, and Storage. Washington, DC. p. 148.

Table 1 Petrophysical properties of the reservoirs

\begin{tabular}{|c|c|c|c|c|c|c|c|c|}
\hline \multirow[b]{2}{*}{ Reservoir } & \multirow[b]{2}{*}{ Reservoir parameters } & \multicolumn{7}{|c|}{ WELL } \\
\hline & & TAJ 23 & TAJ 24 & TAJ 15 & TAJ 25 & TAJ 27 & TAJ 30 & Average (m) \\
\hline \multirow{6}{*}{$\mathbf{A}$} & Thickness (m) & 24 & 26 & 29 & 26 & 31 & 45 & 30.16 \\
\hline & $\begin{array}{l}\text { Cap rock thickness } \\
\text { (m) }\end{array}$ & 67.05 & 54.86 & 67.05 & 76.2 & 67.05 & 76.2 & 68.07 \\
\hline & Net-to-Gross & 0.72 & 0.84 & 0.90 & 0.55 & 0.89 & 0.13 & 0.67 \\
\hline & Water Saturation & 0.38 & 0.40 & 0.42 & 0.40 & 0.37 & 0.57 & 0.43 \\
\hline & Porosity & 0.23 & 0.21 & 0.20 & 0.22 & 0.23 & 0.15 & 0.21 \\
\hline & Permeability $(\mathrm{mD})$ & 1466.82 & 1296.17 & 1208.74 & 1381.68 & 2281.44 & 716.59 & 1391.90 \\
\hline \multirow{7}{*}{ B } & Thickness (m) & 10 & 7 & 12 & 8 & 8 & 40 & 14.00 \\
\hline & $\begin{array}{l}\text { Cap rock thickness } \\
(\mathrm{m})\end{array}$ & 48.77 & 30.48 & 42.67 & 42.67 & 21.34 & 60.96 & 41.15 \\
\hline & Net-to-Gross & 0.36 & 0.61 & 0.25 & 0.32 & 0.71 & 0.39 & 0.44 \\
\hline & Water Saturation & 0.63 & 0.45 & 0.66 & 0.66 & 0.48 & 0.52 & 0.63 \\
\hline & Porosity & 0.14 & 0.20 & 0.10 & 0.13 & 0.18 & 0.17 & 0.15 \\
\hline & Permeability (mD) & 596.90 & 1225.84 & 371.75 & 578.46 & 912.79 & 943.78 & 768.25 \\
\hline & Thickness (m) & 58 & 53 & 61 & 65 & 66 & 73 & 62.00 \\
\hline \multirow{5}{*}{ D } & $\begin{array}{l}\text { Cap rock thickness } \\
\text { (m) }\end{array}$ & 23.38 & 24.38 & 15.24 & 18.29 & 39.62 & 39.62 & 26.92 \\
\hline & Net-to-Gross & 0.47 & 0.80 & 0.58 & 0.57 & 0.91 & 0.53 & 0.64 \\
\hline & Water Saturation & 0.46 & 0.35 & 0.66 & 0.46 & 0.36 & 0.53 & 0.47 \\
\hline & Porosity & 0.20 & 0.25 & 0.18 & 0.20 & 0.24 & 0.18 & 0.21 \\
\hline & Permeability (mD) & 1293.70 & 1849.46 & 1062.88 & 1174.07 & 1656.89 & 989.45 & 1337.74 \\
\hline
\end{tabular}

Table 2 Estimated hydrocarbon volumes in the reservoirs

\begin{tabular}{llll}
\hline Parameter & Reservoir A & Reservoir B & Reservoir C \\
\hline Thickness (m) & 30.16 & 14 & 62 \\
Caprock thickness (m) & 68.07 & 41.15 & 26.94 \\
Porosity & 0.21 & 0.15 & 0.21 \\
Permeability (millidarcy) & 1391.90 & 768.25 & 1337.74 \\
Net To Gross & 0.67 & 0.44 & 0.64 \\
Water Saturation & 0.43 & 0.63 & 0.47 \\
STOOIP (MMSTB) & 27.23 & 6.12 & 184.74 \\
Volume of hydrocarbon produced (MMSTB) & 9.53 & 2.14 & 64.66 \\
& & & \\
\hline
\end{tabular}

Table 3 Summary of resultant storage capacity for the reservoirs

\begin{tabular}{lllllll}
\hline Reservoir & Net Porosity & $\begin{array}{l}\text { Storage } \\
\text { capacity }(\mathrm{MM} \\
\left.\text { Tons } \mathrm{CO}_{2}\right)\end{array}$ & $\begin{array}{l}\text { Storage capacity } \\
\text { factor, } \xi . \\
\left(\mathrm{MM} \text { Tons } \mathrm{CO}_{2}\right)\end{array}$ & & & \\
\hline & & & $1 \%$ & $4 \%$ & $10 \%$ & $15 \%$ \\
$\mathrm{~A}$ & 0.21 & 18.5 & 0.185 & 0.74 & 1.85 & 2.775 \\
$\mathrm{~B}$ & 0.15 & 4.10 & 0.041 & 0.164 & 0.41 & 0.615 \\
D & 0.21 & 125.00 & 1.25 & 5.00 & 12.50 & 18.70 \\
Total & 147.60 & 1.476 & 5.904 & 14.76 & 22.09 \\
\hline
\end{tabular}


Table 4 Site selection criteria for safety and security of $\mathrm{CO}_{2}$ storage (IEA GHG, 2009)

\begin{tabular}{lll}
\hline Parameter & Selection Threshold (IEAGHG 2009) & This study \\
\hline Reservoir Lithology & $\begin{array}{l}\text { Sandstone, Dolostone, Limestone and Siltstone for oil and } \\
\text { gas reservoirs }\end{array}$ & Sandstone \\
Depth to top & $\geq 800 \mathrm{~m}$ & $3310 \mathrm{~m}-3539 \mathrm{~m}$ \\
Reservoir thickness & $>10 \mathrm{~m}$ & $14 \mathrm{~m}-62 \mathrm{~m}$ \\
Porosity & $>10 \%$ & $15 \%-21 \%$ \\
Permeability & $>200 \mathrm{mD}$ & $768 \mathrm{mD}-1392 \mathrm{mD}$ \\
Storage capacity & $4 \mathrm{Mt} \mathrm{CO}_{2}$ for oil and gas reservoirs & $420 \mathrm{Mton}$, \\
$\begin{array}{l}\text { Reservoirs-seal pairs; extensive } \\
\text { and competent barrier to }\end{array}$ & Intermediate and excellent; many pairs (multi-layered & Many pairs (growth faults) \\
vertical flow & system) & \\
Caprock lithology & & \\
Caprock thickness & Salt, Anhydrite, Shale or Claystone & Shale \\
Geothermal gradient & $\geq 10 \mathrm{~m}$ & $41 \mathrm{~m}-68 \mathrm{~m}$ \\
& Gradients $<35^{\circ} \mathrm{C} / \mathrm{km}$ and/or low surface temperature & 13.46 to 33.66 \\
\hline
\end{tabular}

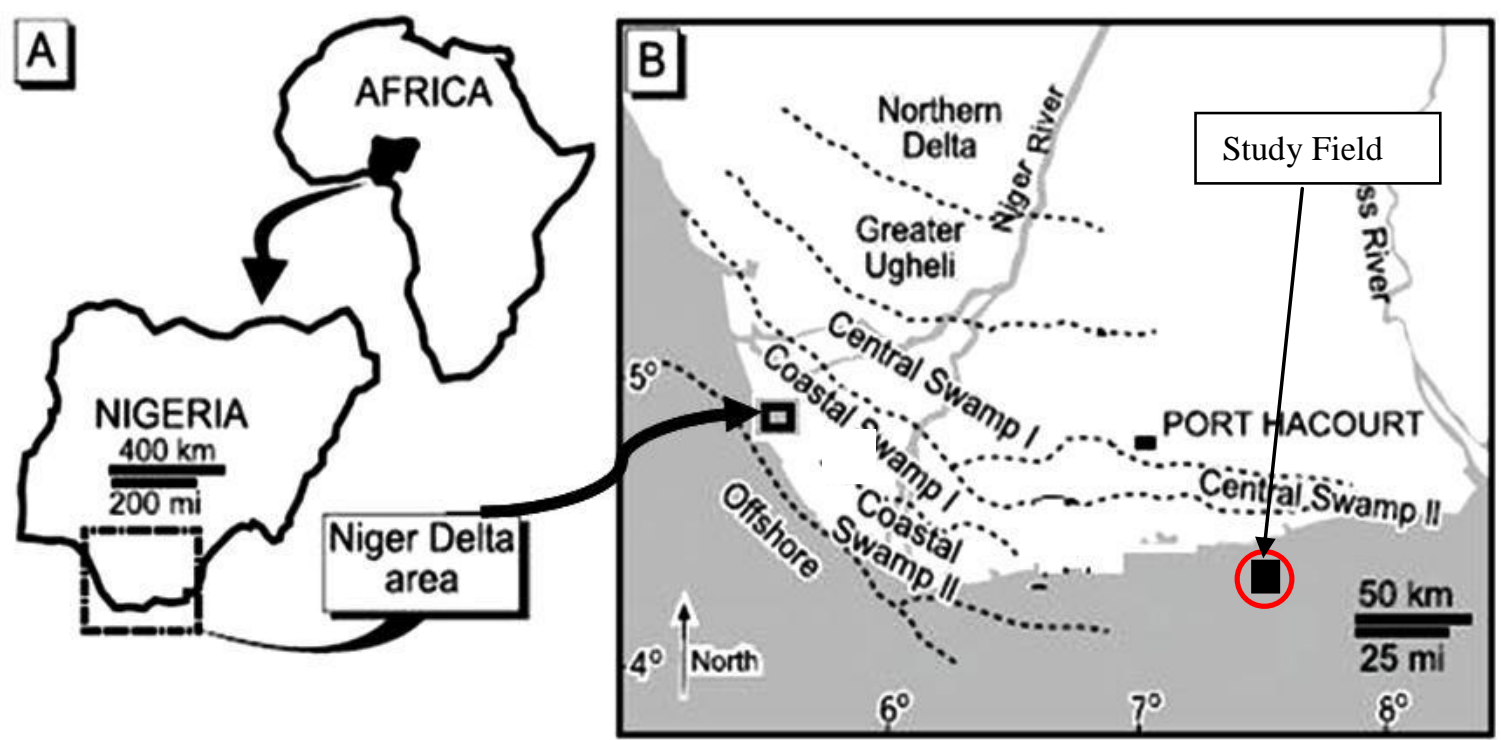

Fig. 1 General map of the Niger Delta showing the depobelts and approximate location of the study field (modified from Ahiarakwem and Opara 2012). 


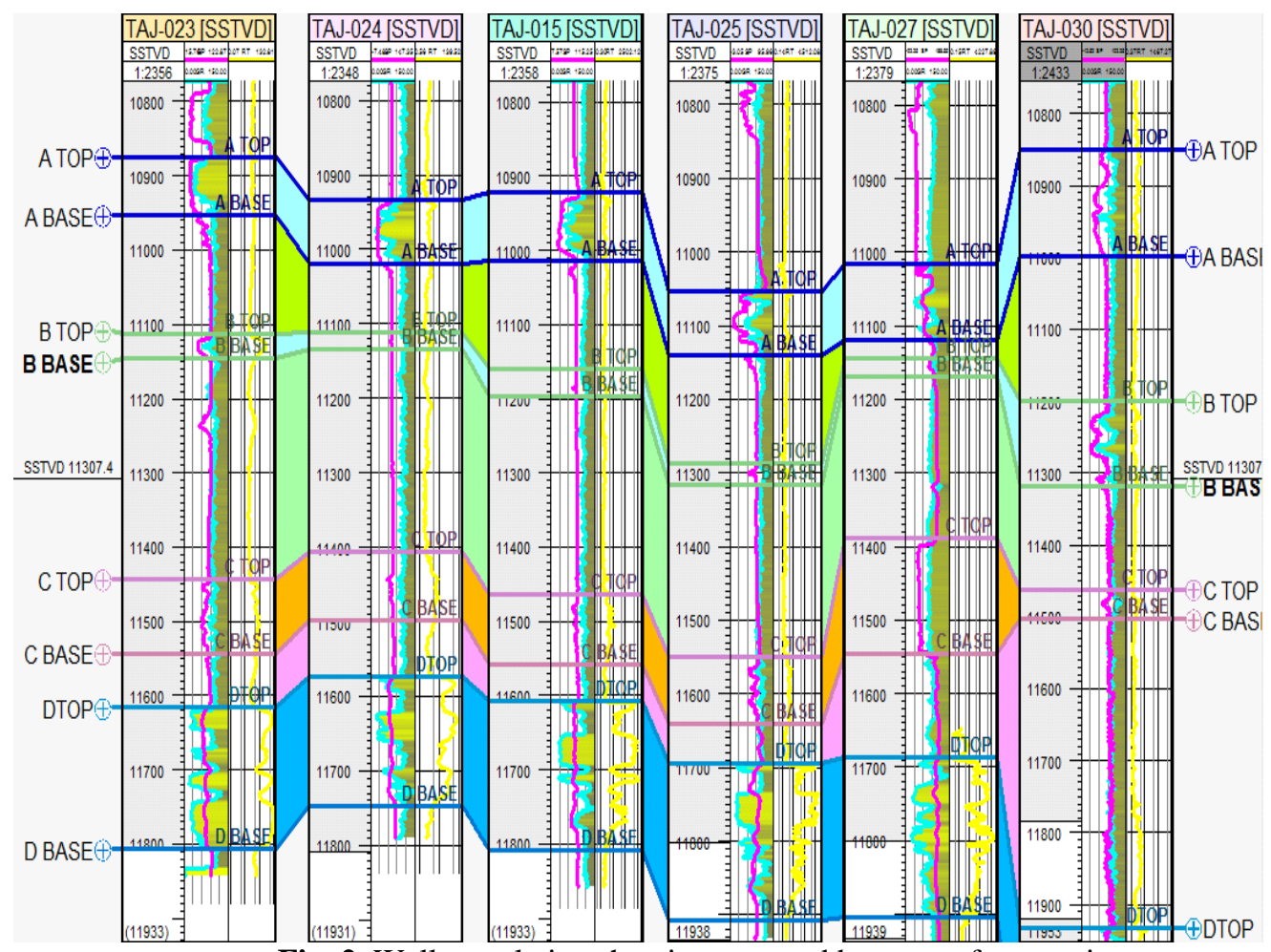

Fig. 2 Well correlation showing tops and bottoms of reservoirs

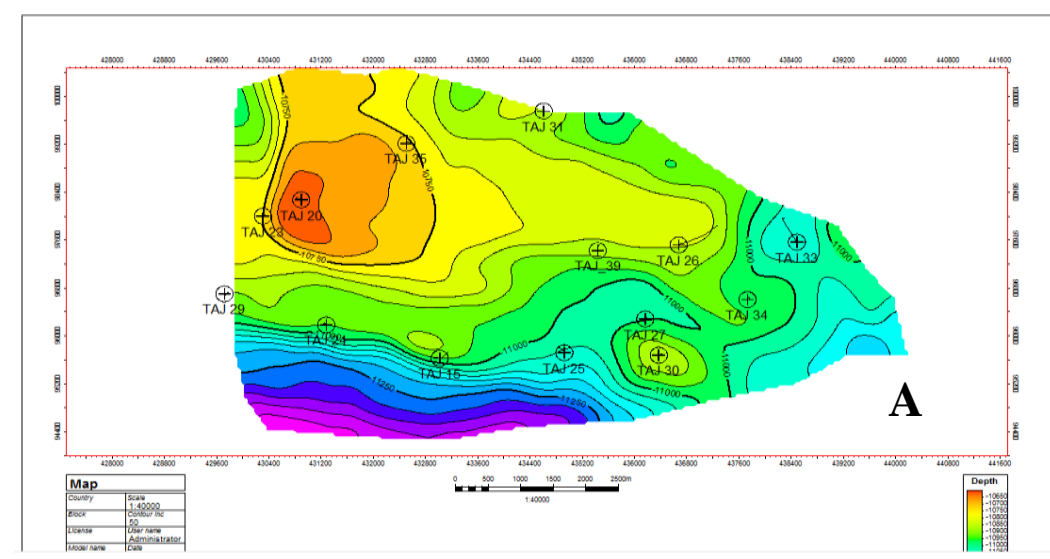

Fig. 3a Depth structure map for reservoir A 


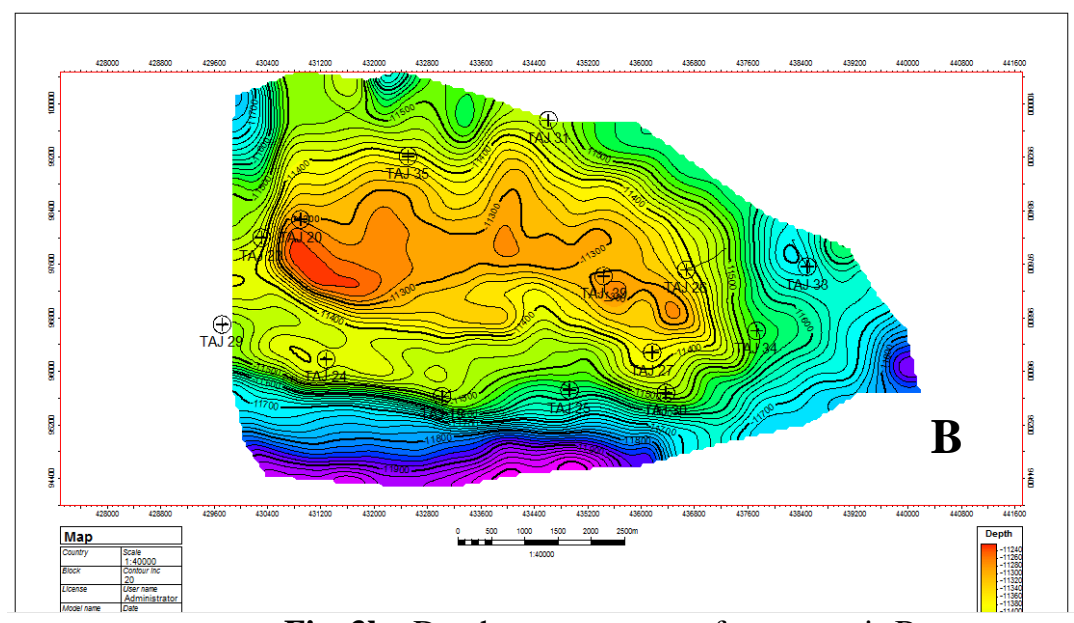

Fig. 3b Depth structure map for reservoir B

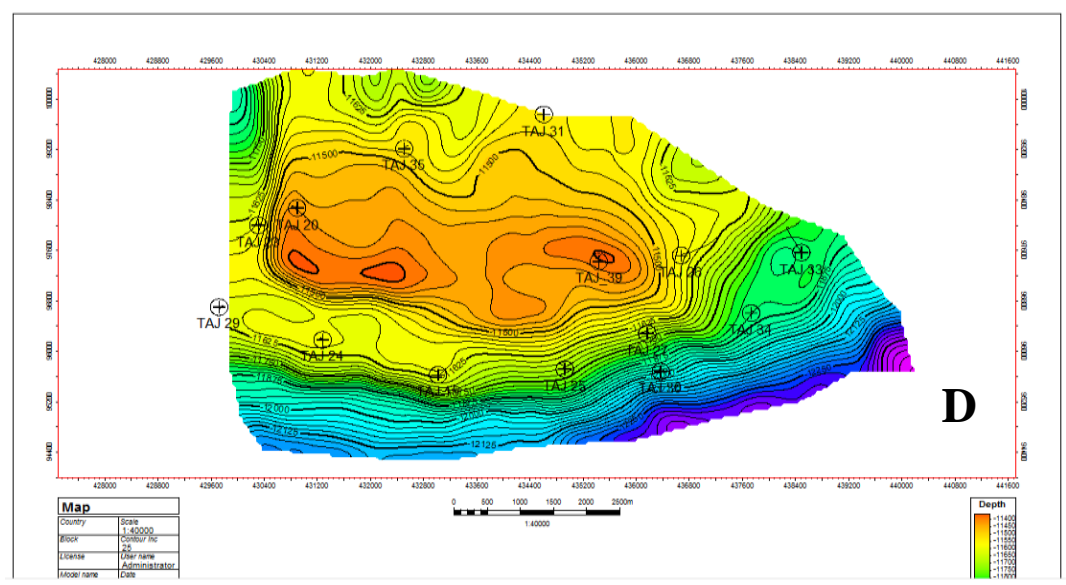

Fig. 3c Depth structure map for reservoir D

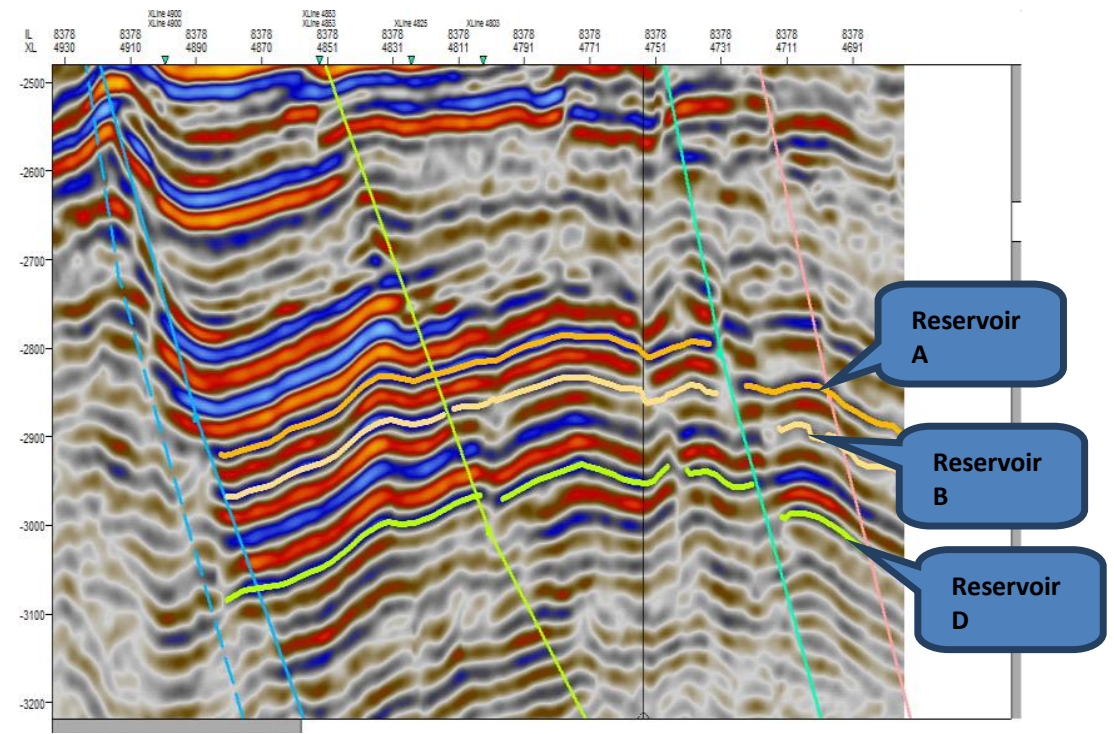

Fig. 4 Interpreted seismic section showing the fault system and the reservoirs 